\title{
Line Item Budgeting on Labor Costs to the Level of Income
}

\author{
Abdalla \\ Economics Department, Faculty of Economic and Social Studies, University of Khartoum, \\ Sudan \\ Received: August 2, 2020 \\ Received in Revised: August 11, 2020 \\ Accepted: August 13, 2020
}

\begin{abstract}
Library research is a data collection technique through the library in the form of literature books, and lecture materials that are relevant to the problem under study. In this study, the authors used the following data collection methods Research library (library research) It is a data collection technique through the library in the form of literature books, and lecture materials that are relevant to the problem under study. Field research (field research) is direct retrieval of the object under study by taking the following steps Observation, namely data collection through direct observation of the object under study, Interviews, namely conducting interviews with leaders and parties interested in the object of research.
\end{abstract}

Keywords: Library Research, Costs, Budgeting, Labor

\section{Introduction}

Line with the development of the business world, the problems faced by the company are getting more and more complex. The challenges faced by all companies without exception are required for a good management system to anticipate problems that will arise and be able to develop the company. Companies as an economic institution are generally established to obtain optimal benefits. This can only be realized if the company can effectively and efficiently allocate its resources in carrying out its business activities.

One of the management functions is planning (planing), planning is an action based on facts and assumptions regarding the description of activities carried out in the future. The relationship between budgeting and company planning shows a management function consisting of planning, actuating, controlling. Of the three management functions have a close relationship with budgeting is planning The more developed and advanced a company is, the more complex its activities will be. Activities in each section must be planned carefully, one form of the plan is compiled in the company budget (Business Budget) in the coming period. The increasing complexity of the problem causes many activities to be carried out based on careful planning. Budget or a complete Business Budget is one form of various plans that may be drawn up, although not every plan can be called a budget. In every company, one of the elements of production costs that has a big influence on the product is the cost of labor. Labor costs are greater than all costs combined, although this is not a problem, effective and systematic planning of labor costs is important because it will benefit both the company and the employees themselves.

Labor costs include all expenses for employees, namely top-level executives, management personnel, labor staff, supervisors, and educated and uneducated workforce. In general, labor is classified as direct and indirect. The grouping is related to the preparation of a budget for each of these costs and how the nature of the costs. Direct labor costs include labor costs that are directly involved in the production process and these costs are easily related to the output, while indirect labor costs are not easily related to the output. The direct labor budget includes 
the need for direct labor that is planned to produce various types and quantities of output that are planned in the production budget. It is generally preferable to prepare a separate budget for direct labor and include indirect labor in the factory overhead budget. The rationale for using a separate direct labor budget is to provide planning data on the number of direct labor required, the number of direct labor, labor costs per product unit, and cash flow requirements. Another purpose of the direct labor budget is to form the basis for direct labor control.

All of the above aspects do not only apply to one level, but at all levels of position in the company. So it is clear that labor costs are a fairly large component of the cost of goods produced. Mistakes of the leaders in terms of labor will have an effect on the price of goods produced, so that it also affects the company's position in competition. Often the person in charge of the budget program has to justify an increase from the previous budget, the same budget amount as the previous year is usually deemed necessary without any checks.

As Line Item Budgeting is an old budgeting system so it is better known as traditional budgeting, in general, companies use this model in budgeting because this model is relatively easy and simple. A budget is only a tool, however good a budget is, it will not function properly if the people who use the tool cannot use it properly. In connection with the description above, the author raises the title "Line Item Budgeting Analysis on labor costs against income levels at PT Sermani Steel Corporation Makassar". From the background stated, the authors take the following main problems. How is the application of Line Item Budgeting on labor costs and its effect on the level of income at PT Sermani Steel Corporation Makassar.

\section{Definition of Budget}

The word "budget" is a translation of the word "budget" in English. However, the word actually comes from the French word "bougette" which means a small bag (a small bag). In English history, this term was first used in 1733 when the finance minister brought a leather bag inside which contained a financial proposal he would submit. . At that time the minister said "open the budget" (Edwards, et.al, 2002) and then the term budgeting continued to develop. Historically at the outset, the budget was viewed as a rigid tool, having more of the properties that required limiting spending. This view has developed into a good and broader view, namely a view that sees budgeting as a process of how a company uses its existing resources. The definition of budget from various literatures is as follows: According to Wilks (2011) A budget is a periodic financial plan that is compiled based on approved programs and a written plan regarding the activities of an organization which are stated quantitatively and generally stated in unit of money for a certain period.Then, according to Gordon \& Loeb (2006) states that the budget is a form of statement rather than management plans and policies that are used in a certain period as a guide or a blue print in a certain period. According to Stilley et al. (2010), the budget is the result of planning in the form of a list of various integrated activities, both in terms of revenues and expenses which are stated in units of money and a certain period of time usually in one year. Furthermore, according to Rasmussen \& Andreasen (1959) suggest that the budget is a statement regarding the estimated performance to be achieved during a certain period which is stated in financial measures.

The budget as a planning tool must also pay attention to the relationship between one budget and another and is a process of developing company goals and selecting activities carried out in the future to achieve these goals. This process includes determining company goals, developing environmental conditions so that these goals can be achieved, selecting actions to be taken to achieve these goals, determining steps to translate plans into actual activities, re- 
planning to correct deficiencies that occur. The budget serves as a tool to coordinate the plans and actions of various units or segments within the organization so that they can work in harmony towards achieving goals. It should be noted that coordination must be endeavored, so that it cannot be expected to run automatically because each individual in the organization has different interests and perceptions of organizational goals. The process of aligning the relationships between employees and their workers in order to be connected to achieve company goals. This activity consists of dividing work among groups, individuals, and coordinating relationships between individual and group activities.

If an organization is to function efficiently, it must determine the channels of communication through and the various units within the organization. Communication includes the delivery of information relating to objectives, strategies, policies, plans, implementation, and irregularities that arise. In preparation, various units and levels of the organization communicate and participate in the budget process. Furthermore, everyone who is responsible for the nutrient budget is assessed on their performance through the product control report. The budget also functions as a tool to motivate executors in carrying out tasks or achieving goals. Motivating the implementers can be encouraged by providing incentives in the form of prizes in the form of money, awards, etc. to those who achieve achievements. The budget can function as a means of controlling activities because the budget that has been approved is the commitment of the implementers who participated in the preparation of the budget. Basically, control is the comparison between the plan and the implementation so that irregularities can be determined whether it has become a "red flag" for the organization or its units. These deviations are used as a basis for evaluation or performance appraisal and feedback for future improvements. Often the terms planning and control are confused and often the two terms are used for the same purpose, a good budget system must be associated with planning and control, good planning without effective control results in waste of funds and time. On the other hand, without planning control cannot be carried out towards the goal to be achieved.

\section{Educational Function}

The budget also serves as a tool to educate managers on how to work in detail at the accountability center they lead and at the same time connecting with other accountability centers in the organization concerned. Thus, the budget is useful for leadership training for managers or prospective managers so that in the future they will be able to occupy a higher position.

According to Kundel \& Walsh (1993) classifying the budget is very important in preparing a budget, by grouping the budget it will be easier to compile the desired type of budget according to the needs. The budget can be grouped from several aspects, including: Segi Dasar Penyusunan.

According to the basis of preparation, the budget consists of Variable budget (variable budget) is a budget that is arranged based on a certain interval (range) of capacity (activity) and is essentially a series of budgets that can be adjusted to different levels of activity (activity). Fixed budget (fixed budget) is a budget that is prepared based on a certain level of capacity. In terms of Arrangement Method, the budget consists of Periodic Budget (periodic budget) is a budget that is prepared for a certain period. In general, the period is one year which is compiled at the end of each period.Anggaran Kontinu (continuous budget) is a budget that is made to make improvements to the budget that has been made. 


\section{Budgeting Model}

According to Cordery \& Graham (1989), In budgeting practices in various countries and the business world, the budgeting model has been developed according to the needs, situations and conditions. Several types of budget models have been developed as follows:

\section{Line Item Budgeting}

This model is an old form of budgeting so it is known as traditional budgeting. Business organizations and the public sector generally use this model in budgeting because this model is relatively straightforward and simple.

\section{Incremental Budgeting}

straightforward and simple.Incremental Budgeting Budgeting with this model basically uses line item budgeting, but is done by adding or subtracting the value of the budget from the previous year, and this method is very conservative with relatively small changes or with certain limits based on adequate considerations. However, its weaknesses allow for income and expenses that are no longer in line with realityPlanning Programing Budgeting Sistem

The PPBS model was developed to enable decision makers to make decisions based on calculations or a scientific approach from existing financial management models. This model uses cost and benefit analysis. The budgeting unit covers a wide program area (economy, health, education) with different implementers. its advantages are comprehensive, program implementers can compete, while the weaknesses are no clear priority, and the ideal portion of the budget for each unit is difficult to know.

\section{Performance Budgeting}

With this model, the budget is compiled based on the measurable performance of various activities. However, this method also uses object-based classifications such as line item budgeting. The determining factor in this method is the efficiency of various existing activities by setting a cost standard. With these cost standards, a budget for the following year is prepared and is usually adjusted according to logical considerations. And focus on the performance (performance) or the results of the program which is determined based on the aspirations of the company.

\section{Zero Based Budgeting}

As the name implies, the budget is compiled from Zero even though the budgeting process had been carried out in the previous year. The budget does not depend on the previous year, so this is the opposite of the incremental budgeting method, which often finds ineffective programs, but the budget actually increases. Its advantages are providing certainty about the amount of the budget, clearer policy direction, while the weaknesses in determining priorities take longer and frequent markups occur.

\section{Labor}

Manpower includes people who are currently working, who are looking for work and who do other activities such as going to school or taking care of the household. In practice, the definition of labor and not labor is only differentiated by age limits, although in some countries there is no uniformity regarding the use of this age limit. This is because the conditions of each country are far different from one another. According to Kahn (2010), states that labor is a minimum age limit of 10 years without a maximum age limit. Therefore, workers are meant as residents aged 10 years or more. The definition put forward by Payaman J. Simajuntak regarding the absence of an age limit for workers includes the fact 
that generally in Indonesia who have undergone retirement do productive activities. This is possible because the state has not been able to provide adequate social benefits. Thus, an effort to increase income is to carry out productive business activities, especially in the private sector.

\section{Labor Costs}

Labor costs are one of the conversion costs, in addition to factory overhead costs for converting raw materials into finished products. According to Suggs \& Lewis (2003), in relation to products, labor is divided into direct labor and indirect labor. Direct labor is all employees who are directly involved in producing the finished product, whose services can be measured directly by the product, which is a big part of producing the product. Direct labor wages are treated as direct labor costs and are calculated directly as an element of production costs. Workers whose services cannot be directly traced to the product are called indirect labor. This indirect wage is called indirect labor cost and is an element of factory overhead costs. Indirect labor wages are charged to indirect products, but through specified factory overhead costs. Cooper \& Willis (2009), states that the cost of labor is the price charged to use human labor. According to Kazahaya (2005) states that labor costs are expenses which are expected to provide benefits in the future in terms of income realization. Based on this definition, it can be assumed that labor costs are the amount measured in units of money, namely expenditures in cash or in the form of transfer of wealth, services provided in connection with goods and services to be obtained or to be achieved.

\section{Costs}

Income in principle has the character of adding or increasing the value of the company's owner's assets, both in the form of receipts and in the form of rights and claims. For a clearer understanding of this income, we can follow the explanations put forward by several experts as follows: According to Bridgman (2018) Income is the gross addition in capital, as a result of company activities. Meanwhile, according to Frechtling (2000). Revenue is the gross mass flow of economic benefits arising from the normal activities of the corporate entity during a period, if the inflow results in an increase in net assets that do not come from investment contributions.

\section{Operational definition}

Line Item Budgeting is a budgeting process that is based solely on the amount of realization of the previous year's budget and the costs budgeted for a need which are made as separate lines. Cost is the amount measured in units of money, namely expenditures in cash or in the form of transfer of wealth, share capital expenditures, services provided in connection with goods and services to be obtained or to be achieved. Direct Labor Cost is the cost of labor in the production section and is easily related to the output, is variable or proportional to the output and this cost is planned in the direct labor budget. A budget is a periodic financial plan that is prepared based on approved programs and a written plan regarding the activities of an organization which is stated quantitatively and generally expressed in units of money for a certain period of time. Income is the gross addition in capital, as a result of the company's activities.

\section{Conclusion}

The results of the implementation fom these various definitions, it can be seen that the cost is an expense that can be measured in terms of money that must be made to achieve a certain goal in the future. Or it can also be said to be a sacrifice that is issued now and is expected to bring results in the future. It can be concluded that costs are expenses that are economically unavoidable but predictable in a production process to produce goods and services. Income is 
the gross addition in capital, as a result of the company's activities. Cost is the amount measured in units of money, namely expenditures in cash or in the form of transfer of wealth, share capital expenditures, services provided in connection with goods and services to be obtained or to be achieved.

\section{References}

Bridgman, B. (2018). Is labor's loss capital's gain? Gross versus net labor shares. Macroeconomic Dynamics, 22(8), 2070-2087.

Cooper, R., \& Willis, J. L. (2009). The cost of labor adjustment: Inferences from the gap. Review of Economic dynamics, 12(4), 632-647.

Cordery, I., \& Graham, A. G. (1989). Forecasting wheat yields using a water budgeting model. Australian Journal of Agricultural Research, 40(4), 715-728.

Edwards, J. R., Boyns, T., \& Matthews, M. (2002). Standard costing and budgetary control in the British iron and steel industry. Accounting, Auditing \& Accountability Journal.

Frechtling, D. C. (2000). Assessing the Impacts of Travel and Tourism-Measuring Economic Benefits'. International Library of Critical Writings in Economics, 121, 9-27.

Gordon, L. A., \& Loeb, M. P. (2006). Budgeting process for information security expenditures. Communications of the ACM, 49(1), 121-125.

Kahn, L. B. (2010). The long-term labor market consequences of graduating from college in a bad economy. Labour economics, 17(2), 303-316.

Kazahaya, G. (2005). Harnessing technology to redesign labor cost management reports: labor costs typically represent over 50 percent of a hospital's total operating expenses. Can the data management process be harnessed to create meaningful labor cost management tools?. Healthcare Financial Management, 59(4), 94-101.

Kundel, H. L., \& Walsh, C. (1993). Preparing a research grant application budget. Investigative radiology, 28, S13-S16.

Rasmussen, W. C., \& Andreasen, G. E. (1959). Hydrologic budget of the Beaverdam Creek basin, Maryland (No. 1472). USGPO,.

Stilley, K. M., Inman, J. J., \& Wakefield, K. L. (2010). Planning to make unplanned purchases? The role of in-store slack in budget deviation. Journal of consumer research, 37(2), 264-278.

Suggs, D. N., \& Lewis, S. A. (2003). Alcohol as a direct and indirect labor enhancer in the mixed economy of the BaTswana, 1800-1900 (pp. 135-149). University of Arizona Press, Tucson.

Wilks, B. W., Morales, R., Garcia, R., \& Pacheco, R. A. (2011). U.S. Patent No. 7,895,102. Washington, DC: U.S. Patent and Trademark Office. 